\title{
Stalo se to před sto lety
}

Vážení čtenáři,

divná a současně smutná věc se dne 28. června roku 1914 stala. V Sarajevu, v hlavním městě zemi bosenské součásti císařství rakousko-uherského, dvěl kulky z pistole srbského nacionalisty vyšly. První kulka zasáhla jeho arcivévodu knížete Františka Ferdinanda d'Este ${ }^{2}$, následníka trůnu, a druhou jeho chot' Žofii, ${ }^{3}$ rozenou Chotkovou. Od té doby již nikdy nebylo nic tak, jako tomu bylo dřive. Začala válka, lidé začali houfně umírat, na frontě i v zázemí, kulkou, plynem, zbraněmi jiného i moderního druhu a také hladem. Zásluhou generálů ruku v ruce $\mathrm{s}$ jejich ambicemi a neschopností trvala válka déle než čtyři roky.

Zbraně utichly, válka skončila a vítězné mocnosti se rozhodly restrukturalizovat politické uspořádání světa. A tak sen o samostatném českém státě se nakonec stal skutečností a zrodila se Československá republika. S novým státem přišla nová měna, československá koruna. Byly vytvořeny nové finanční, bankovní a měnové instituce a pražská burza obnovila svoji činnost. Ekonomicky i finančně se vedení nového státu podařilo od bývalého Rakousko-Uherska velmi rychle izolovat.

Není však ekonomického úspěchu bez ekonomické vědy, a není ekonomické vědy bez ekonomického vzdělání. Za Rakouska-Uherska probíhala ekonomická výuka v českém jazyce na Karlo-Ferdinandově univerzitě v Praze (dnešní Karlově univerzitě), na Císařské a královské vysoké škole technické v Praze (dnešní České vysoké učení technické) a částečně i na Císařské a královské vysoké škole technické v Brně (dnešní Vysoké učení technické v Brně). Ze strany českých průmyslníků a obchodníků se objevovalo volání po založení samostatné české vysoké obchodní školy, avšak čas pro tuto školu ještě nenadešel. Za války skomírají školy, učebnice se odkládají do kouta a učitelé i studenti odcházejí na frontu.

Česká ekonomická (národohospodářská) věda té doby pouze postupně přijímala myšlenky ekonomického liberalismu. ${ }^{4}$ Spor mezi konzervativními staročechy a liberálními mladočechy, který se např. promítl i do definování odborných pojmů v Ottově slovníku naučném, pak ostře zasáhla válka a představitelé mladočechů v čele s Karlem Kramářem a Aloisem Rašínem byli odsouzeni $\mathrm{k}$ smrti (rozsudek nicméně vykonán nebyl). Koneckonců za války na vydávání knih a článků z oboru ekonomického není stejně čas.

Teprve po skončení války mohla česká ekonomická věda plně uplatnit své schopnosti. Alois Rašín se stal prvním ministrem financí nové republiky a úspěšně uskutečnil měnovou a finanční reformu. Dočkalo se také české školství, slavnostně byla založena Vysoká obchodní škola se sídlem v Praze ${ }^{5}$ jíž Vysoká škola ekonomická v Praze považuje za svoji předchůdkyni.

1 Mýtus „o sedmi kulích“ vychází z knihy Hašek, J.: Dobrodružství dobrého vojáka Švejka I-II. Praha, Státní nakladatelství krásné literatury, hudby a umění, 1955, s. 23.

2 Plným jménem a tituly jeho korunní princ Franz Ferdinand Carl Ludwig Joseph Maria von Österreich-Este.

3 Plným jménem a tituly Sophie Maria Josephine Albina Gräfin Chotek von Chotkowa und Wognin, vévodkyně z Hohenburgu.

4 Nejstarší vědecká díla českých ekonomů Albína Bráfa, Josefa Grubera, Františka Ladislava Chleborada, Josefa Kaizla, Františka Cyrila Kampelíka, Jana Kolouška, Josefa Pazourka, Jana Loevensteina, Františka Ladislava Riegera a Aloise Rašina byla digitalizována a jsou volně k dispozici na internetu, blíže viz VŠE: Zlatý fond českého ekonomického myšlení. [online], Praha, Vysoká škola ekonomická, c2014, [cit. 1. 4. 2014], $<$ http://www.econlib.cz/zlatyfond/index.htm>.

5 Zákon č. 461/1919 Sb. ze dne 23. července 1919, kterýmž zřizuje se československá státní „Vysoká škola obchodní v Praze“. Prvním děkanem této školy se stal profesor Josef Pazourek. O sídlo této školy toužila neúspěšně i Olomouc. 
$\mathrm{Na}$ východ od našich hranic se začal prosazovat ještě jeden značně odlišný ekonomický vědecký směr, a to marxisticko-leninská politická ekonomie. O dvacet let později, na dočasnou dobu, celých jednačtyřiceti let, ovládl tento poněkud zvláštní styl ekonomického chápání světa i naši ekonomiku, a dovedl ji ke krásně vypadajícím Potěmkinovým vesnicím, ale to už je asi na jinou předmluvu.

Po dvaceti letech po skončení první světové války vypukla další světová válka. A po jejím skončení jsme byli svědky mnoha dalších, byt' trochu menších válek. Avšak ,ve válce mlči múzy"6 a k múzám patří i múza vědy a múza pedagogiky ${ }^{7}$ Nechme proto múzy, aby mohli pracovat, neobtěžujme je malichernými válkami, a oni se nám pak odmění inspirací i pro náš výzkum, pomohou nám napsat vědecky přínosný článek, který - a snad to není příliš velká troufalost - bude následně opublikován v Českém finančním a účetním časopise.

prof. Ing. Petr Marek, CSc.

předseda redakční rady

Českého finančního a účetního časopisu

6 Výrok „Inter arma silent Musae“ je přikládán římskému filozofovi Cicerovi, ve skutečnosti však jde pouze o obměnu jeho výroku „Inter arma enim silent leges“ (Cicero: Pro Milone). V češtině je tento výrok známý pak hlavně z textu písně „Král a klaun“ od Karla Kryla.

7 Přiznávám, že řecká mytologie se o múze vědy a múze pedagogiky nezmiňuje, osobně však o jejich existenci nemám vůbec žádné pochybnosti. 